総＼cjkstart説第56回総会シンポジウム

\title{
上顎骨前方部延長術
}

一術式と要点一

\author{
飯田征二
}

\section{Maxillary anterior segmental distraction osteogenesis}

\author{
IIDA Seiji
}

\begin{abstract}
Maxillary anterior segmental distraction osteogenesis (MASDO) is a rather new surgical orthodontic treatment to produce an ideal maxillary dental arch form in patients with cleft lip and palate. Different from total maxillary advancement by DO, this surgical procedure can solves the problems in the small and retruded maxilla without the risk of deterioration of velopharyngeal function, because the distracted segment is only made at the anterior part of the maxillary bone.

To advance the anterior segment in only a single vector, a single palatal bone-borne distractor or toothborne distractor is effective, but two hybrid type distractors on each side of alveolar process can produce some rotational movements of anterior segment by controlling advancement amount in each side. Therefore, this procedure solves not only the size of maxillary arch but also the shape of deformed dental arch.

As bone height and width at distracted space on alveolar process is enough for fuature alignments of crowding teeth or anterior movement of molars, this treatment is an effective pre-orthodontic surgical treatment for solving discrepancy of maxillary dental arch.
\end{abstract}

Key words: maxillary bone (上顎骨), distraction osteogenesis（仮骨延長術）, cleft lip and palate（口唇口蓋裂）

\section{緒言}

骨延長術の顎顔面領域への導入は，顎変形症の治療に多 大な影響を及ぼし ${ }^{1)}$ 特に, 口唇口蓋裂にみられる上顎骨 の前方発育不全症例に対して，大きく貢献したことは明ら かである。それらの治療のなかでも, Le Fort骨切り術を用 いた全上顎骨の前方への延長術は，軟口蓋への形態的影響 の少なさや，口唇周囲組織の緊張の影響の緩和など，一期 的移動術でみられた問題点を解決できることから, 現在で は, 口唇口蓋裂治療の標準的な治療の 1 つとして認識され ている。しかしながら, 前方への移動量や軟口盍の疲痕の 程度, 術前の鼻咽腔閉鎖機能の状態によっては, これら治 療によっても鼻咽腔閉鎖不全が生じる可能性があり, また, これら疾患を有する患者でみられる前後的に狭小化してい

岡山大学大学院医茵薬学総合研究科䫟口腔再建外科学分野

Department of Oral and Maxillofacial Reconstructive Surgery, Okayama University Graduate School of Medicine, Dentistry and Pharmaceutical Sciences

\section{る上顎㐘列弓の形態の解消には至らない.}

上顎骨前方部延長術（Maxillary Anterior Segmental Distraction Osteogenesis: MASDO）は，上顎柬列弓内で骨 切りを行い, 後方部をアンカーとして前方部の上顎骨セグ メントのみを前方に延長し, 上顎菊列弓の前後径の回復を 行う手術方法である(写真 1,2$)$. 本術式では前方移動に 伴う軟口盍への影響をより軽減できているため, 術前の鼻 咽腔閉鎖状態に関わらず上顎骨前㐘部を移動させることが できるなど, その適応症例は潜在的に多いものと考えられ る.

我々が行っている MASDO の術式ならびに有効性につい てはすでにいくつかの報告を行っているが ${ }^{1 \sim 4)}$, 本稿で は，その詳細な術式と注意すべき点について報告を行う。

\section{適応症例}

上顎㐘列の前後的劣成長を示す症例が適応症例となる. 本術式ではセグメントへの栄養が主に口蓋粘膜からとな 


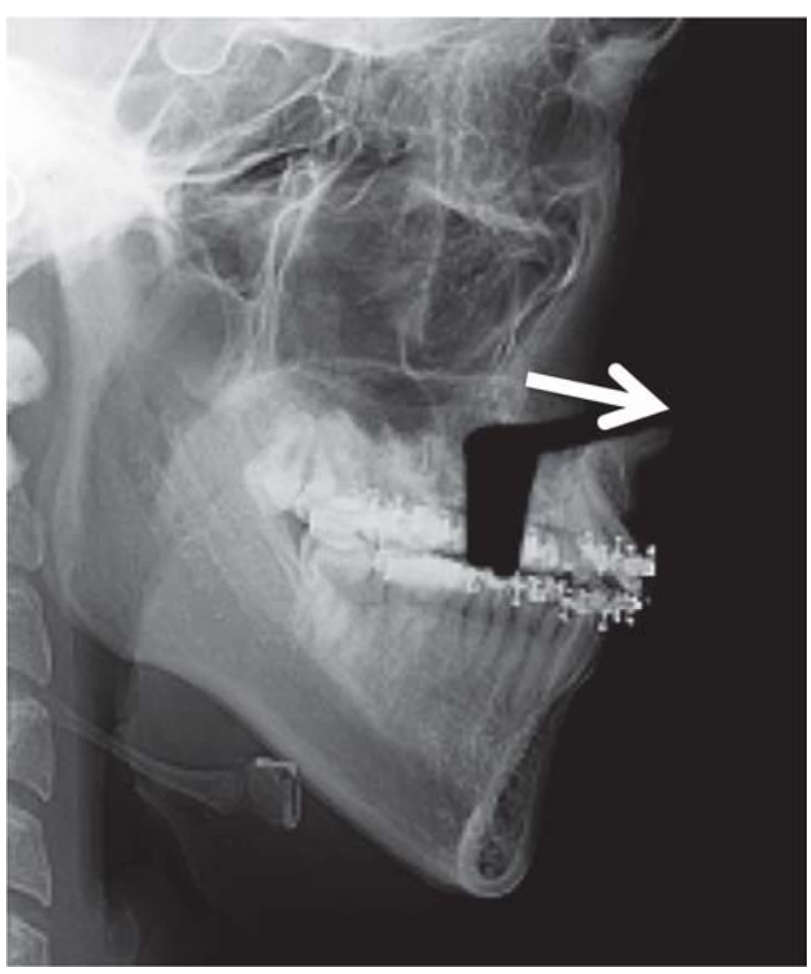

写真 1 MASDO の概念図

上顎骨前方部のみの移動のため, 後方部の形態的変化 を生じない臼柬の咬合関係。鼻咽腔閉鎖機能は温存され る。

るため, 粘膜の付着面積が広いほど安全であることからセ グメントは大きいほうが安全である。そのため, 顎裂部の 骨移植術が行われ, 前方部セグメントが一体となって移動 できることが望ましい.

なお，骨分割時の隣接する歯の柬根の損傷あるいは蒾根 尖の露出を避け, 安全に手術を行うため, 㐘術前の矯正治 療により, 骨切り線を設定する歯の㐘根の間に骨切りを十 分なスペースを設けられていることが望ましい.

\section{治 療術式}

\section{I . 術前の準備およびデバイスの選択}

\section{1 ） $3 \mathrm{DCT}$ および三次元実態モデル}

3DCT により上顎骨や口蓋骨形態の評価ならびに歯根間 のスペースの確認を行う。特に, 口蓋部にデバイスを設け る場合，固定源の位置を決定する上で必須となる。また， 骨と柬を固定源とする Hybrid Type としてデバイスを使用 する場合には本データをもって三次元実態モデルを作成 し，固定位置の設定とデバイスの適合操作に用いる。

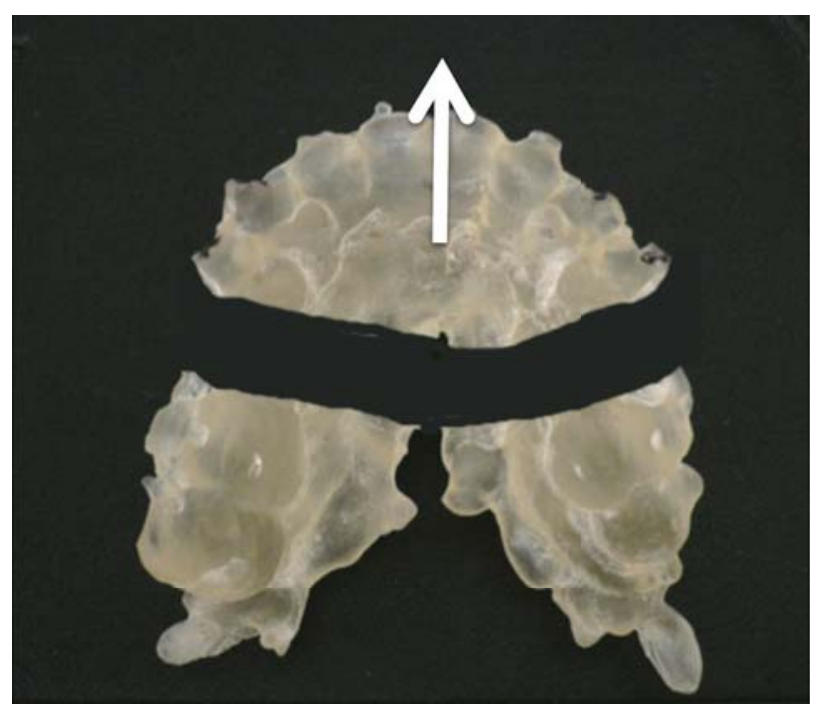

写真 2 MASDO の概念図 前後的に狭小化した上顎歯列形態の改善が行える.

\section{2 ) デバイスの選択}

本手術ではさまざまな市販の延長装置を用いることがで きるが，本論文では，DynaForm System (Leibinger Strykar 社製）を用いた術式を紹介する.

セグメントの移動量が左右同じ場合 (平行移動) は， 1 個のデバイスを口蓋骨に経粘膜的に固定する方法（BoneBorne type）で行える。一方, 左右で延長量が異なり，セ グメントに回転運動を求める場合は, 両側の骨切り線をま たぐ形で歯ならびに骨に固定を求める方法 (Hybrid Type) としてデバイスを用いる。なお，七グメントの三次元的動 きの付与は延長段階では確実性をもって行うことは困難で あり, 最終的な位置修正は延長終了後の顎間铍引あるいは 矯正治療によって行うことになる。

\section{II. デバイスの準備}

\section{1 . 口蓋部にデバイスを設置する場合}

（1）仮骨延長後の想定模型を元に，延長方向を術前模型 上に印記し，その方向に沿ってデバイスの位置ならびにア 一ムを調整する。スクリュー挿入部は 3 次元 CT な゙から 口蓋骨形態, 㐘根の位置を把握した上で決定する。なお， アームの先端に挿入したスクリューリングは, 付属の器具 にて筒状の挿入部を圧接変形させてアームと固定する.

(2) サージカルステントの作成

デバイスを術前に設定した場所で正確に固定することは 困難である, そのため, 術中にスクリュー挿入部をガイド 


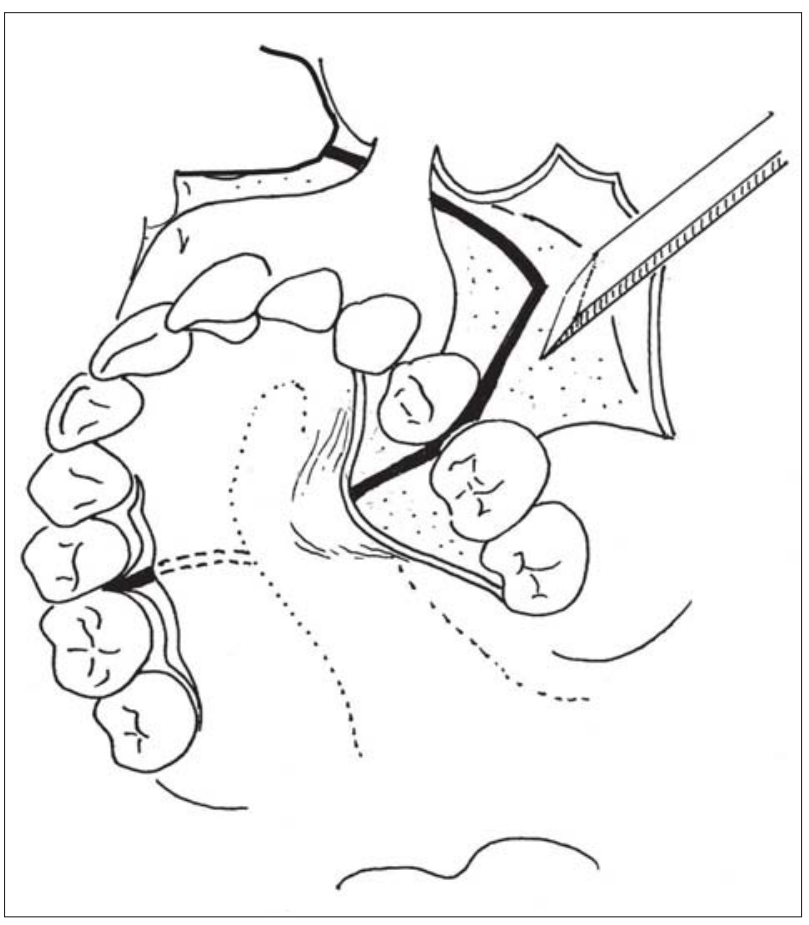

図 1 骨切りの模式困

セグメントへの血流に十分配慮した手術操作が要求さ れる。柬槽部の骨分割時には柬根の位置関係に注意を払 う。.

し明記するためのステントを準備する必要がある。術前の 上顎柬列模型上で圧接法などでスプリントを作成し，口蓋 部のスクリュー挿入部に穴を設けサージカルステントとし て用いる。

\section{2. 頓側にデバイスを設置する場合（Hybrid Type で デバイスを用いる場合)}

三次元実態モデル上で固定源を決定し，それに合わせて デバイスのアームの屈曲とその先端へのスクリューリング (骨固定部) あるいはスクリューフォーク（柬固定部）の 装着を行う。

\section{III. 骨切りの術式}

\section{1 ）切開と剥離}

口蓋裂症例では，前方部口蓋骨への栄養の確保に十分な 注意を払う必要があり，唇側よりの血流の確保に留意する 必要がある。そのため, より安全に手術を行う上で, 術野 の明示は制限されるが，唇側からの血流を確保するため前 柬部の切開と後方部の切開は連続させず，唇側の骨面の剥 離はトンネル状にて行うのが望ましいと考えている。

口蓋粘膜に対しては，歯頸部にそって切開を行い，骨切

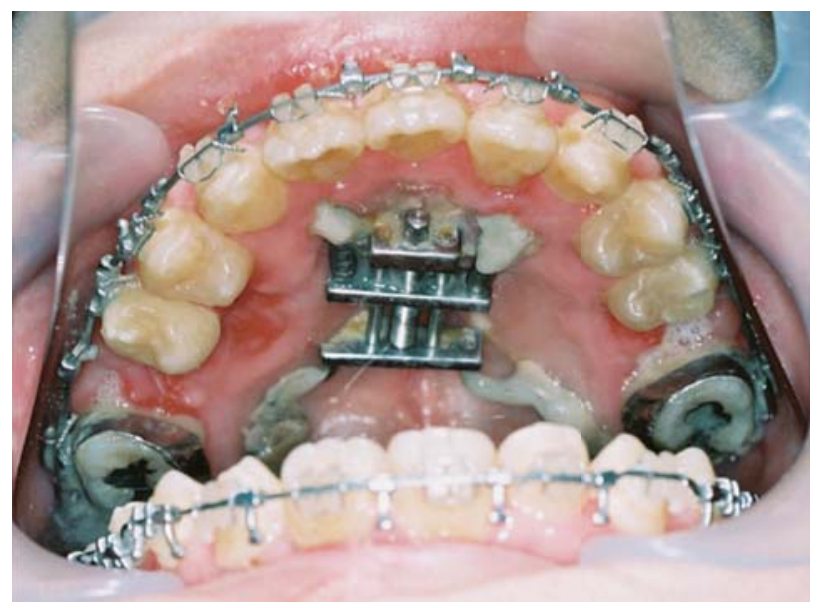

写真 3 口蓋部デバイスでの MASDO

デバイスは経粘膜的に挿入したスクリューで口蓋骨と 連結されるため，即時重合レジンでの被覆による固定が 必要である。

りを行う口盍骨面を明示する必要があるが，前方部の粘膜 付着を損なわないように配慮を行わなければならない.

\section{2 ) 骨切り (図 1)}

上顎骨煩側は，レシプロケーティングソーまたは細い フィッシャーバーにて行う.

鼻腔側壁の骨切りは, 口蓋側の骨切り線より後方までレ シプロケーティングソーにて行い，鼻中隔軟骨は，鼻中隔 マイサーで鼻腔底より離断する。

口蓋側の骨切りは，トンネル状に口蓋粘膜を十分挙上し た上で，レシプロケーティングソーにて確実に骨切りを行 う。㐘槽骨部の骨切りは, 歯根の関係に十分配慮して行い, 最終的に煩側と口蓋側の骨切り線を薄刃マイサーにて連続 させ，ダウンフラクチャーを行う。その際隣接柬の根の露 出状態ならびに骨片の十分な可動性を確認する。

\section{N デバイスの固定と延長}

\section{1 . ロ蓋部にデバイスを設置する場合（写真 3）}

1-1）デバイスの位置決めと固定

骨切りを終了後, サージカルステントを装着させて上顎 骨を離断前の状態に復位させる。次いで，スプリントに設 けたスクリュー挿入位置決め用の穴より, 口蓋粘膜のスク リュー挿入部にマーキングを行う。

デバイスのスクリューリングをマーキングした部位に位 置させ，スクリューリングを通して口蓋骨に粘膜上よりド リル（コントラアングル エンジン）で口蓋骨を貫通させ て，十分な長さのスクリューを挿入し固定する。 
なお，セグメント部での口蓋骨はある程度の厚みを期待 できるが, 後方部の固定減となる大田㐘部の口蓋骨は薄く またその面積も狭い。そのため, 誤った位置にドリリング を行った場合（スクリューの固定ができない位置），再度 のドリリングを行わなければならないが，その場合には骨 の脆弱化を生じるなど，スクリュー固定が期待できなくな る可能性がある。そのため, 必ず, 位置関係を確認し, 後 方部からの固定を行うことが肝要であり，設計の際には十 分な骨の形態の評価を行っておく必要がある.

もし，十分な骨の固定が後方部で得られない事体が生じ た場合は，すみやかに，確実な固定源を得る場所に骨固定 位置を変更し，それに合わせてデバイスのアームの調節を 行う。あるいは, 後述する Hybrid Type への変更を考える.

なお，経粘膜的にスクリューを骨に植立するため，これ のみでは強固な固定は行われない.スクリューリングが粘 膜を圧迫し沈み込まない位置でスクリューの締め込みを終 え, 模型上で想定した三次元的位置とした上で，スクリュ ーリングと粘膜との間隙ならびに骨に植立したスクリュー の間隙を即時重合レジンで確実に埋めて固着連結すること によりデバイスの固定とする.

延長ロッドを回転させ延長を数 $\mathrm{mm}$ 程度試み, 上顎骨の 移動に干渉する箇所がないことを確認し, 元の位置まで戻 す.

なお, 梨状口に近接して索引用の金属プレートを装着し， 術後のフェイスマスクによる前方率引に用いる。

\section{1-2）延長操作}

術後フェイスマスクを装着させ, 知正用エラスティック ゴムにてアンカープレートあるいは矯正装置で前方率引を 行う. 1 週間の待機期間の後, $0.5 \mathrm{~mm} \times 2$ 回 / 日で延長を 行う.

本方法では，術前に装着された矯正装置になんら影響を 与えおらず, また，唇側煩側の操作が可能であるため, 延 長終了後ただちにこれら矯正装置を用いて㐘列を連続させ て固定させる。その際，延長により生じたにスペースにス ペーサーを設置し，唇圧による蒌ならびにセグメントの後 戻りに対する処置を行わなければならない，また，固定が 極めて薄い口盍骨の 2 本のスクリューによってのみなされ ているため, 後戻りの応力に対して抗するだけの強度はほ とんどない。そのため, フェイスマスクによる牽引の維持 が肝要であり，延長に打いては後戻りを十分加味した延長 を行う必要がある。

\section{$1-3$ ) デバイスの除去}

術後 2 〜 3 月程度でデバイスを除去し, 矯正治療によ る歯の移動を開始する。後戻りの力によりでデバイスは後

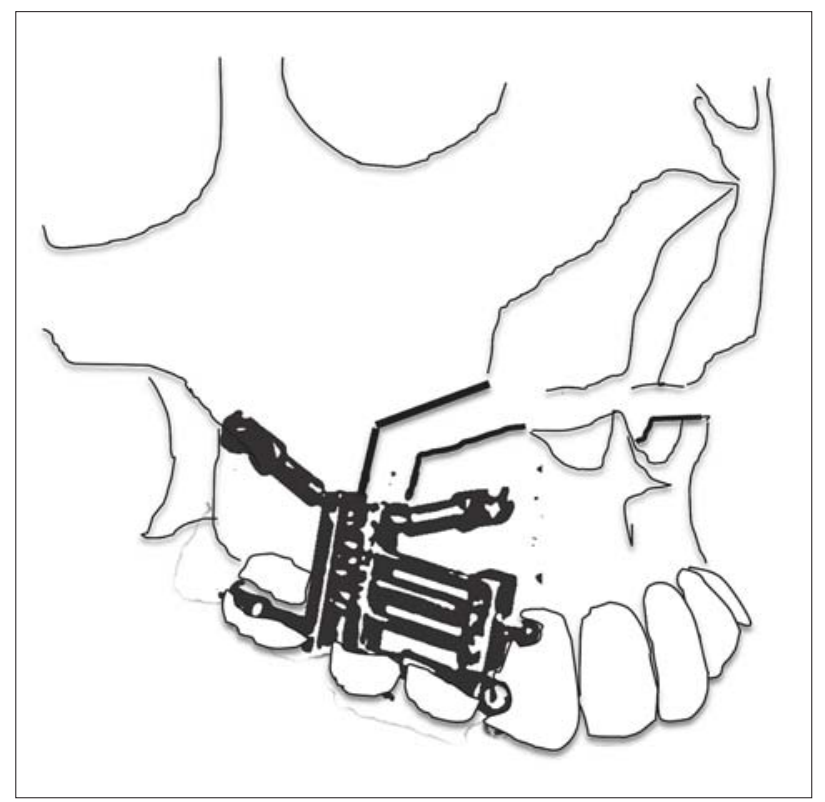

図 2 Hybrid type デバイス装着の模式図 骨とはスクリューで, 歯とはワイヤーで矯正装置と固 定する。

方に移動する傾向があるため, 後方部のスクリューは骨か ら緩んでいる場合が多く，また，そのスクリューヘッド部 も軟口蓋側に移動し, 粘膜に被覆されることもある。デバ イスの除去は外来局所麻酔下にて行える。しかし，スク リューヘッドを覆っているレジンがへッドの切れ込みに入 り除去しにくくなっている場合があるので, 注意が必要で ある。

\section{2. 頓側にデバイスを設置する場合（図 2, 写真 4)}

$2-1)$ デバイスの位置決めと固定

切開ならびに骨切りに関しては，上述の術式と同様であ る.

ダウンフラクチャーした後, 元の位置関係に復位し, デ バイスを固定する。この際，㐘列側でスクリューフォーク と矯正装置を $0.3 \mathrm{~mm}$ ステンレスワイヤーにて緩く仮固定 を行い，その上で, 骨部の固定位置を修正して最終固定位 置を決定し, ドリリングを行い, $2.0 \mathrm{~mm}$ 径セルフタッピン グスクリューで固定を行う。その後に, 歯列側のワイヤー を締め込み，歯列側の最終固定を行う（ワイヤー固定のみ では延長時の弛みが生じるため, 閉創後に即時重合レジン で被覆を行う)。

両側のデバイスの固定が終了した段階で，延長を行い， 干渉なく前方移動が行われることを確認する.

デバイス本体が齦煩移行部の最深部に位置し，切開線が デバイスの裏側に位置することになるので, 通常の縫合操 


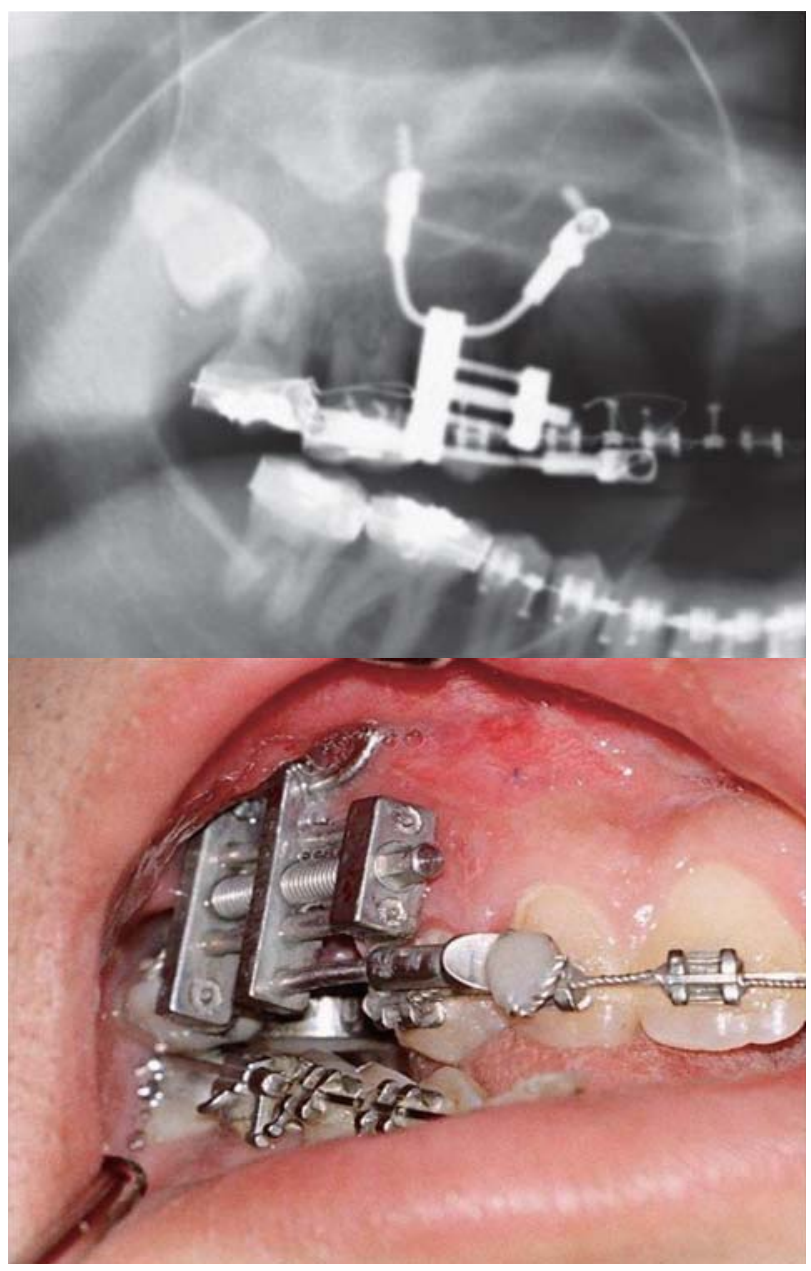

写真 4 Hybrid type デバイスでの MASDO 上顎骨と歯に固定源を有するため, 口蓋部にデバイス を用いた方法に比べ強固な固定と確実な延長が行える。

作はできない，そのため，確実な閉創を行うためにはデバ イスの固定の前にあらかじめ粘膜弁に縫合糸を通すなどの 配慮が必要である。骨の露出の程度によるが，固定した状 態での可及的な閉創に心がけることで十分と考えている. ただし, 骨切り部に関しては骨膜での完全な被覆を行う. 延長による粘膜部の裂開を防ぐ上で本部位での粘膜骨膜弁 での完全閉創は最も重要である.

\section{$2-2)$ 延長操作}

1 週間の待機期間の後, $0.5 \mathrm{~mm} \times 2$ 回 / 日で延長を行う. なお， 口蓋部にデバイスを設けた場合と異なりセグメント の可動性は少ないため早期からのフェイスマスクによる毫 引は必要がない。しかし, 延長が進むと骨の接触面積の減 少から可動性が大きくなり，また，セグメントは上方へ偏 位する傾向が生じてくる。その際には，ゴムによる顎間率 引を行い, セグメントの誘導を行う。
煩側のデバイスにより口唇粘膜面への機械的刺激が持続 するため, 口蓋部デバイスの延長と異なり, 異物感が強 く，デバイスによる裷瘡性潰瘍を形成することがあるた め, 軟膏ガーゼなどで刺激部の被覆等を行う必要がある. なお，これら機械的刺激はセグメントの前方への移動があ る程度進むと減少する。

なお，2つのデバイスの平行性を保つことはできない. しかし本装置の骨固定が 1 本のスクリューのみで, しかも 薄い上顎骨との間で行われていることから, 過度な機械的 応力は後方の骨固定部において集中し固定スクリューのゆ るみが生じる。これにより応力の解消が生じることから， 平行性のないことによる延長操作の不具合は生じることは 少ない.ただし, 延長後のセグメントの可動性が生じるこ とから, 顎内固定, 顎間率引などの処置を施し, セグメン トの後戻りに対する対応を行う必要がある。

\section{$2-3 ）$ デバイスの除去}

エックス線で延長部の骨化の状態を観察し, 術後 $2 \sim 3$ か月以上経過した段階でデバイスの除去を行う.

\section{考察}

MASDO は成長障害を呈した上顎による反対咬合の改善 のみならず, 小臼柬部での延長により Discrepancy の改善 を図ることができることから，口蓋側に転位した㐘の誘導 など理想的な歯列を作成することに貢献できる。そのた め, 本手術は矯正治療の最終段階の外科的治療ではなく, 矯正治療の一過程に貢献する手術方法に分類される。上顎 骨前方部のみを延長する方法は, 我々の報告の他に, いく つかの症例報告をみることができる ${ }^{5 \sim 10)}$. それら報告で は，矯正用の拡大スクリューを用いた Tooth-Borne type の 延長装置を用いた報告が多いが，それ以外にもさまざまな 延長装置が用いられている。今回，延長装置として用いた DynaForm システム (Stryker Leibinger GmbH \& Co.KG.) は, 本来下顎骨の仮骨延長用に設計された創内型延長装置 であり, 延長装置に附属するアームの形状ならびにその先 端に装着するチップを調整することにより，骨のみではな く㐘列に装着された矯正装置にも延長の固定源を求めるこ とができるように設計されている。したがって, 症例に 応じて固定源を変更し, Bone-borne Type あるいは Hybrid Type として使い分けができるシステムであり，固定源に 苦慮する口唇口蓋裂症例に対する MASDO においては有用 な延長装置といえる.

本術式は視野が限られる手術ではあるが基本的にセグメ ントへの血流の確保と骨切り線に隣接する歯根の損傷の回 避, 確実なデバイスの固定を念頭に置けば, 十分に簡便な 
術式であるといえる。しかしながら，骨の接触が極めて少 なくなる前方方向への延長であるため, むしろ術後での後 戻りを含めたセグメントの位置の維持確保に綿密な矯正的 管理が必要な治療であり, 口腔外科医と矯正歯科医との極 めて密な連携が要求される面がある.

上顎骨を人為的に前方に“成長”させる本手術は，これ ら成長が幼少期に障害された口唇口蓋裂と症例に対して有 用な外科的矯正治療のひとつであると考えている.

\section{引用文献}

1 ) 飯田征二 : 䪽顔面の骨延長術 . 近畿東海矯正菊科雑 誌 46: 15-19, 2012.

2 ）飯田征二：口唇口蓋裂症例に対する上顎骨仮骨延 術 Maxillary anterior segmental distraction osteogenesis. 日口科誌 56: 9-11, 2007.

3 ) Iida S, Yagi T, et al : Maxillary anterior segmental distraction osteogenesis with the dynaform system for severe maxillary retrusion in cleft lip and palate. Plast Reconstr Surg 120: 508-516, 2007.

4 ) Aikawa T, Haraguchi S, et al : Rotational movement of the anterior maxillary segment by hybrid distractor in patients with cleft lip and palate. Oral Surg Oral
Med Oral Pathol Oral Radiol Endod 110: 292-300, 2010.

5 ) Karakasis D and Hadjipetrou L : Advancement of the anterior maxilla by distraction (case report). J Cranio-maxillofac Surg 32: 150-154, 2004.

6 ) Bengi O, Karaçay S, et al : Cephalometric evaluation of patients treated by maxillary anterior segmental distraction: A preliminary report. J Cranio-Maxillof Surg 35: 302-310, 2007.

7 ) Wang XX, Wang X, et al : Anterior maxillary segmental distraction for correction of maxillary hypoplasia and dental crowding in cleft palate patients : a preliminary report Int J Oral and Maxillofac Surg 38: 12371243, 2009

8 ) Alkan A, Baş B, et al : Maxillary anterior segmental advancement of hypoplastic maxilla in cleft patients by distraction osteogenesis: report of 2 cases. J Oral Maxillofac Surg 66: 126-32, 2008.

9 ) Richardson S, Agni NA, et al : Anterior maxillary distraction by tooth-borne palatal distractor. J Oral Maxillofac Surg 65: 1044-1049, 2007.

10) Bevilacqua RG, Ritoli EL, et al : Midmaxillary internal distraction osteogenesis : Ideal surgery for the mature cleft patient. Plastic Reconstr Surg 121: 17681778, 2008. 